\title{
Legal Certainty of the Notary Peace Act in Bankruptcy Law
}

\author{
Iqbal Tamrin, S.H. \\ Email: iqbaltamrin1922@gmail.com \\ Faculty of Law, Universitas Jember \\ Dr. Ermanto Fahamsyah, S.H., M.H. \\ Email: ermanto_fahamsyah@yahoo.co.id \\ Faculty of Law, Universitas Jember \\ Dr. Ivida Dewi Amrih Suci, S.H., M.H., M.Kn. \\ Email: ivida68dewi@gmail.com \\ Faculty of Law, Universitas Jember \\ DOI: 10.31364/SCIRJ/v9.i07.2021.P0721868 \\ http://dx.doi.org/10.31364/SCIRJ/v9.i07.2021.P0721868
}

\begin{abstract}
Peace agreements that have been homologated through the PKPU process are sometimes denied by debtors. If the homologated peace agreement is denied by the debtor, the creditor may apply for the cancellation of the peace agreement so that the peace agreement is canceled and the debtor is declared bankrupt. An application for annulment of reconciliation can be submitted if it meets the conditions for bankruptcy as regulated in the provisions of Article 170 paragraph (1) of Law Number 37 of 2004 concerning Bankruptcy and PKPU. The approach method used in this research is normative juridical. The purpose of the study was to find out the suitability of the curator's authority at the verification stage with the principle of legal certainty and to find legal certainty on the strength of binding the peace deed in the bankruptcy decision. The result of this research is that the curator is at the verification stage by eliminating the PKPU peace deed causing inconsistencies in his authority. The PKPU peace deed which has been homologated has executive power as the judge's decision which has permanent legal force, in accordance with the legal basis, namely Article $130 \mathrm{HIR} / 154$ RBg which was later modified in the form of PERMA Number 01 of 2008 and PERMA Number 1 of 2016.
\end{abstract}

\section{Keywords: Peace Deed, PKPU, Bankruptcy, Curator's Authority}

\section{Introduction}

Law is one of the tools required by everyone in filling their lives, especially in the economic system in globalization era. These needs are in the form of clear legal regulations and have legal certainty as well as firm law enforcement actions of law enforcement officials. One of the legal apparatus in the civil sector is Notary as a public official (Openbaar Ambtenaar) who must be professional, because it represents the State in making a deed as evidence in the form of an authentic deed. ${ }^{1}$

As an official who makes deeds related to civil law and in accordance with the authority given by the State or Government as outlined in the Article 15 of the Law on Notary Positions Number 2 of 2014 is referred to as UUJN, namely, making an authentic deed as a perfect written evidence, directly related with the law of evidence and as a part of civil law called as Burgerslijk Wetbook. ${ }^{2}$

Bankruptcy law is regulated in Law Number 37 of 2004 concerning Bankruptcy and Suspension of Debt Payment Obligations, as referred to the Bankruptcy Law and PKPU. It also regulates the curator based on the Article 69 of the Bankruptcy Law whose duty is to administer and/or settle the bankruptcy estate. According to the bankruptcy law, the curator is Balai Harta Peninggalan or an individual appointed by the Court to manage and settle the assets of the bankrupt debtor under the supervision of the Supervisory Judge. ${ }^{3}$

A. A. Andi Prajitno, Pengetahuan Praktis Tentang Apa dan Siapa Notaris di Indonesia, The Sixth Edition. (Surabaya: CV. Perwira Media Nusantara, 2020), p. 2.

2 Ibid, p. 4.

${ }^{3}$ See the stipulation of the Article 1 paragraph (5) of the Constitution Number 37 of 2004 concerning Bankruptcy and Postponement of Debt Payment Obligation.

www.scirj.org

(C) 2021, Scientific Research Journal

http://dx.doi.org/10.31364/SCIRJ/v9.i07.2021.P0721686

This publication is licensed under Creative Commons Attribution CC BY. 
The task of managing and settling bankrupt assets is carried out by the curator based on the Article 116 and the Article 117 of the Bankruptcy Law, namely the obligation to reconcile creditors' receivables to make a list of recognized and disputed receivables including the reasons in a separate list. Furthermore, the Law Number 37 of 2004 concerning Bankruptcy and PKPU also regulates reconciliation, namely at the PKPU stage in the Article 222 paragraph (2) that debtors who cannot or expect not to be able to continue paying their debts, may request a postponement of the obligation to pay debts with a view to submit a reconciliation plan which includes an offer or all of the debt to creditors. ${ }^{4}$

In relation to bankruptcy law, a deed can also be formed at the stage of peace mediation for Suspension of Debt Payment Obligations (PKPU). This deed is approved by the parties and it can be made before a notary referred to as a peace deed according to PERMA Number 1 of 2008 and 2016 concerning the Mediation Process in Court. ${ }^{5}$ Of course, it is expected that the parties to the deed can provide legal certainty between those who are in dispute.

The peace deed is expected by the parties in the future to be useful for the parties and can provide justice among those in dispute. However practically, at the verification stage in the bankruptcy procedural law at the Commercial Court, a PKPU peace deed which is agreed upon by the parties and homologated by the court is not executed properly. Certainly, this is what creates legal uncertainty from the peace deed among parties, judges, and the communities in understanding the meaning of the peace deed itself.

As the decision of the Supreme Court of the Republic of Indonesia Number: 77/ Pdt.Sus-Renvoi Procedure/2015/PN. Commerce. Jkt. Pst, jo. Number: 77/Pdt.Sus/ PKPU/2015/PN. Commerce. Jkt. Pst jo. Number: 77/Pdt. Sus/Bankrupt/2015/PN. Commerce. Jkt. Pst. and Supreme Court Decision Number: 4/Pdt. Sus-Other Lawsuits/2020/PN. Commerce. SMG. Jo. Number: 01/Rev. Sus-PKPU/2015/PN. SMG. Jo Number: 11/Rev. Sus-Bankruptcy/2017/PN. Commerce. Smg, there is a deed agreed by the parties through an examination at the PKPU stage which has been homologated by the Court, recalculated by the curator at the verification stage, and that the case is submitted to the Court. The decision has legal force (inkracht van gewisde), so that if it is related to the legal certainty of an authentic deed in court proceedings and agreed upon by the parties, the legal material is not in accordance with the substance of the Article 1870 of the Civil Code as one of the basic binding powers of a party.

As a result of the inconsistency of the provisions of the Articles 116 and 117 of the Bankruptcy Law and PKPU with the Article 281 of the Bankruptcy Law and PKPU which regulates reconciliation, it creates legal uncertainty of a peace deed produced in court proceedings and has been homologated by the Commercial Court. On the basis of these thoughts and considerations, we intended to find out future arrangements for the legal certainty of the PKPU peace deed in the bankruptcy decision agreed by the parties and approved by the Court (homologation).

\section{Statement of Problem}

In this study, we focused on the authority of the curator at the verification stage by nullifying the deed of settlement for the suspension of debt payment obligations in accordance with the principle of legal certainty, and legal certainty regarding the binding force of the peace deed on the suspension of debt payment obligations in the bankruptcy decision. The results of this study was supposed to theoretically contribute ideas to law science, especially to judges in terms of procedural steps regarding the peace agreement, so that it was made in writing before a notary and submitted back to the court to be confirmed in the homologation decision

\section{Method}

${ }^{4}$ See the stipulation of the Article 222 paragraph (2) and the Article 281 paragraph (1) of the Constitution Number 37 of 2004 concerning Bankruptcy and Postponement of Debt Payment Obligation.

${ }^{5}$ Regulation of the Prime Court Number 1 of 2008 and 2016 concerning Process of Mediation in the Court.

www.scirj.org

(C) 2021, Scientific Research Journal

http://dx.doi.org/10.31364/SCIRJ/v9.i07.2021.P0721686

This publication is licensed under Creative Commons Attribution CC BY. 
This study was normative juridical study which focused on examining the application of the rules or norms in the applicable positive law. This type of study was to provide a systematic exposition of the rule of law that regulated certain legal fields, analyzed the relationship among legal rules, explained some difficult parts to understand in a legal rule, and included some possible predictions of the development of a particular legal rule in the future. ${ }^{6}$ Legal research is different from social research, because law does not belong to the category of social science. Legal science is Sui Generis, where law is a science that has its kind and cannot be grouped in one branch of the three of areas, namely natural sciences, social sciences and humanities. ${ }^{7}$

\section{Results and Discussion}

\section{Curator's Authority at the Verification Stage by Eliminating the Deed of Reconciliation Postponing the Obligation for}

\section{Payment of Debts Associated with the Principle of Legal Certainty}

We limited the discussion at the verification stage in the calculation of debts that had been notarized in the bankruptcy procedural law, especially to examine the truth deeply about the determination of the list of receivables made by the curator. In this part, we concerned on the elements of a peace deed, civil procedural law, curator's authority, the list of receivables, and the elements of determination. Some keywords should be noticed and understood carefully, namely peace deed, civil procedural law, curator authority, list of receivables and determination, because law is a science of meanings. ${ }^{8}$

In legal exposure, there happened an act of determining the contents of the legal rules as accurately as possible. First, examining the meaning of each element in accordance with one of the theories used as an analytical grounding in this study, namely using the elements or aspects of systems theory according to Kess Schuit. The system theory was used to examine and analyze the existing system in the special justice system, namely the Commercial Court regarding the legal certainty of the peace deed. The elements in systems theory included the ideal element; operational element, and actual element.

The ideal aspect was formed from a system of legal meanings consisting of rules, norms, and principles. The meaning of intrinsic value was something 'desired' and 'not desired'. This element consisted of all organizations and institutions established in a legal system. Second, in operational element, if it was associated with the authority of the curator in calculating the notarized debt, the institution was the judiciary. Third, the actual element of this element was the overall decision and concrete action related to the system of meaning of the law. ${ }^{9}$

The term 'deed' in Dutch was called as "acte" or "deed", while in English, it was called as "act" or "deed". 'Deed' is a letter of evidence stating a statement/acknowledgment/decision regarding a legal event made according to the applicable regulations and witnessed and ratified by the authorized official. ${ }^{10}$ According to Mertokusumo, a deed is a signed letter that contains the events that form the basis of a right or an agreement, and intentionally made from the beginning for proof. ${ }^{11}$

The deed has two important functions, namely formal function where a legal act was more complete if a deed was made. The function of evidence is the deed as a means of proof made by the parties bound in an agreement intended for later proof. ${ }^{12}$ To ensure legal certainty, the deed enforced in Indonesia must be made in the form of an authentic deed, including a notarial deed. In the Article 1 paragraph (7) of the Law on Notary Positions, "a notarial deed is an authentic deed made by or before a notary

${ }^{6}$ Dyah Ochtorina Susanti and A’an Efendi, Penelitian Hukum (Jakarta: Sinar Grafika, 2013), p. 11.

7 Tatik Sri Djatmiati and Philipus M. Hadjon, Argumentasi Hukum (Yogyakarta: Gajah Mada Universitas Press, 2005), p.

1.

${ }^{8}$ Ivida Dewi Amrih Suci, Hukum Kepailitan: Karakteristik Hukum Acara Renvoi Prosedur Dalam Perkara Kepailitan, The First Edition. (Yogyakarta: LaksBang Justitia, 2020), p. 180.

${ }^{9}$ Ibid, p. 12.

${ }^{10}$ G. Setya Nugraha and R. Maulina F., Kamus Bahasa Indonesia, (Surabaya: Karina), p. 22.

${ }^{11}$ Sudikno Mertokusumo, Hukum Acara Perdata Indonesia, The Second Edition. (Yogyakarta: Liberti, 2006 ), p. 149.

${ }^{12}$ Sudikno Mertokusumo, Mengenal Hukum Suatu Pengantar, The Third Edition, (Yogyakarta: Liberti, 1999), p. 121-122. www.scirj.org

(C) 2021, Scientific Research Journal

http://dx.doi.org/10.31364/SCIRJ/v9.i07.2021.P0721686

This publication is licensed under Creative Commons Attribution CC BY. 
according to the forms and procedures stipulated in this law". ${ }^{13}$ A notarial deed is a perfect written evidence (volledijg bewijs) stipulated in the Article 1 point 1 and the Article 15 Paragraph (1) UUJN. It is also made to guarantee and obtain absolute legal certainty regarding the certainty of the date, month, year, contents of the deed, time, signature, and place of the deed.

The legal basis attached to the peace deed has been explained in PERMA No.1 of 2008 in the Article 17 which states that:

a. If the mediation results in a peace agreement, the parties (with the assistance of the mediator) must formulate in writing the agreement and signed by the mediator and the parties.

b. The parties must present to the judge on the day of the hearing and determined to notify the peace agreement.

c. The parties can submit a peace agreement to the judge to be strengthened in the form of a peace deed.

In addition, the peace deed also has a legal basis in the Article 1858 of the Civil Code, "all peace deeds have a force among the parties, such as a judge's decision in the final stage", and the Article $130 \mathrm{HIR} / 154 \mathrm{RBg}$ as follows: ${ }^{14}$

(2) If a peace can be achieved, the trial a deed is made where both parties are sentenced to keep the promise to which the letter will be valid and carried out as an ordinary decision.

(3) Such a decision cannot be appealed.

In the operational element, judiciary is the institution associated with the mediation of the peace agreement plan, so that the regulations concerning the Judiciary and its auditing authority must be clear and correct in accordance with its principles. Besides, the institution concerned in bankruptcy law as the most important after the bankruptcy decision was the curator. However, it was highly important to know the authority of the curator, so that his authority could be consistent and did not exceed his authority. Shubhan states, "although the provisions on the curator's responsibility in the Article 1365 of the Civil Code can be considered as overboding provisions. ${ }^{15}$ Besides, practically, many curators abused their power as curators as happened in the bankruptcy case Number: 77/Pdt.Sus-Renvoi Procedure/2015/PN. Commerce. Jkt. Pst jo. Number: 77/Pdt.Sus/PKPU/2015/PN. Commerce. Jkt. Pst jo. Number: 77/Pdt. Sus/Bankrupt/2015/PN. Commerce. Jkt. Pst.

The curator is one of the parties that plays a significant role in a bankruptcy case process. Due to its high task/duty, the requirements and procedures to be a curator by the bankruptcy law were regulated relatively strict. The former law handed over authority only to the Heritage Center (BHP). The inheritance hall acts through its proxy located within the jurisdiction of the court that had declared the debtor bankrupt. In the Bankruptcy Law, those who could act as curators under the Article 70 of the Bankruptcy Law were Balai Harta Peninggalan and other Curators.

Matching of receivables made by the curator is in accordance with the Article 116 of the Bankruptcy Law and PKPU which states that "the curator is obliged to match the calculation of receivables submitted by the Creditor with the records that have been made previously and the statement of the Bankrupt Debtor", and the Article 117 of the Bankruptcy Law and PKPU which states that

"the curator is obliged to include the approved receivables into a list of receivables that are temporarily recognized, while the disputed receivables including the reasons are included in a separate list".

The curator pursuant to the Article 69 paragraph (1) of the Bankruptcy Law states: "the task of the curator is to administer and/or settle the bankruptcy estate". The article does not state that the curator has the authority to cancel the deed of peace that has been agreed upon by the parties during the examination at the PKPU stage, because a peace agreement is basically a document that contains the conditions agreed upon by the parties to end a dispute as the result of a peace effort through the assistance of a mediator

${ }^{13}$ A. A. Andi Prajitno, Kewenangan Notaris: Akta Otentik Notaris, Seri B (Surabaya: CV. Putra Media Nusantara, 2018), p. 5 .

${ }^{14}$ Ibid, p. 5-6.

${ }^{15}$ M. Hadi Shubhan, Hukum Kepailitan, The Sixth Edition. (Jakarta: Kencana, Prenadamedia Group, 2019$)$, p. 109. www.scirj.org

(C) 2021, Scientific Research Journal

http://dx.doi.org/10.31364/SCIRJ/v9.i07.2021.P0721686

This publication is licensed under Creative Commons Attribution CC BY. 
at the PKPU stage, while a peace deed is a deed that contains the contents of a peace agreement and judge's decision that strengthens the agreement peace (homologation).

Based on the authority of the curator, there is an error in the curator's reasoning, because the debt acknowledgment deed has been examined by the PKPU and agreed by parties can be interpreted as a deed of peace, but still re-calculated by the curator as in the Decision of the Supreme Court of the Republic of Indonesia Number: 77/ Pdt.Sus-Renvoi Procedure/2015/PN. Commerce. Jkt. Pst jo. Number: 77/Pdt.Sus/PKPU/2015/PN.Niaga.Jkt.Pst jo. Number: 77/Pdt.Sus/Bankruptcy/2015/PN. Commerce. Jkt. Pst. The existence of Deed of Recognition of Debt No. 117 between Bankrupt Debtor Widji Sudibio Tanuhardjo (in Bankruptcy) on 31 August 2007 made before the Notary Damar Susilowati.

There are some reaosns where the authentic deed was the only evidence that had a high value in the evidence, namely:

1. Authentic deeds; means written evidence as referred to the Article 1868 BW, 164 RIB and 283 RDS.

2. Authentic deeds (from its beginning) were deliberately made as evidence.

3. Authentic deeds made by and before a State official were appointed by law.

4. Based on the Article $1870 \mathrm{BW}$ or $165 \mathrm{RIB}$, an authentic deed provides a perfect proof for parties, their heirs and those who have rights.

5. The authentic deed was not only perfect evidence, but also as binding evidence. It was a perfect proof, where it does not require any additional proof, while binding could mean that anything written in it must be trusted by the judge and truly considered.

About the authority of the curator in the Article 116 of the Bankruptcy Law at the verification stage, if it was not interpreted correctly and provided definite guidelines, it would make the curator as an institution with a broad power, so that it could result the curator as an institution with no boundaries and might result in the management and settlement of bankrupt assets outside of their authority. Therefore, it was necessary to have a definite legal sign to limit the interpretation of the curator's authority, so that it could not change the meaning of the regulation of the curator's authority in the calculation of debt that has been notarized at the PKPU stage. The formulation of the law does regulate an interpretation on the article, so that the formulation conducts a mallinterpretation and causes the regulation of peace agreement regulated in the Article 281 paragraph (1) concerning vagenorm.

\section{Legal Certainty on the Deed of Suspension Settlement of Obligation for the Payment of Debt in a Bankruptcy Decision}

The bankruptcy law was formed to provide a protection to the creditors when the debtor did not pay his debts. The creditors were expected to gain access to the assets of the bankrupt, because the debtor was no longer able to pay his debts. However, the protection provided by the bankruptcy law for the interests of creditors must not harm the interests of the debtor.

A good bankruptcy law must be based on the principle of providing a balanced protection for creditors and debtors (companies). It was necessary to provide legal protection for creditors, because the interests of debtors and creditors were the same. Creditors with uncollectible receivables would make creditors bankrupt to the point of creditor bankruptcy which could further cause losses to stakeholders. When the stakeholders who suffered these losses were important investors, it would be highly influential for the sustainability of the world economy in Indonesia. ${ }^{16}$

Principally, a promise creates an engagement. The existence of an agreement as one of the sources of engagement, the Book III BW regulated engagement, but none of them described an engagement itself. ${ }^{17}$ In its development, the meaning of engagement had changed viewed from Hofman's definition. Engagement is a legal relationship between a limited number of legal subjects in the connection with several people (debtors or creditors) with a grounding cooperation to behave in certain ways towards

${ }^{16}$ Ivida Dewi Amrih Suci and Herowati Poesoko, Hukum Kepailitan: Kedudukan dan Hak Kreditor Separatis atas Benda Jaminan Debitor Pailit, Second Edition (Yogyakarta: LaksBang PRESSindo, 2016) p. 1-2.

${ }^{17}$ Herowati Poesoko, Dinamika Hukum Parate Executie Obyek Hak Tanggungan, Edisi Revisi (Yogyakarta: Aswaja Pressindo, 2013), p. 106.

www.scirj.org

(C) 2021, Scientific Research Journal

http://dx.doi.org/10.31364/SCIRJ/v9.i07.2021.P0721686

This publication is licensed under Creative Commons Attribution CC BY. 
other parties. According to Pitlo, an engagement is a legal relationship and as a property in nature between two or more people on the basis of a right (creditor) and obligation (debtor). Therefore, an engagement depends on the type of agreement in the parties. ${ }^{18}$

Bankruptcy law has the principle of debt. In the bankruptcy process, the concept of debt is highly decisive, because it is impossible for bankruptcy cases to be examined. Without debt, the essence becomes nothing, because bankruptcy is a legal institution to liquidate debtors' assets to pay creditors' debts. If the debt principle is analyzed, it is the fulfillment of the general confiscation principle, where the debtor's debts must be repaid by making sales of the debtor's assets. The management of bankrupt assets and the supervisory judge should obey the general confiscation principle, and comply with the principle of a fair legal certainty.

The meaning of the peace deed contains the value of justice as the concept of justice of Hari Chand which includes substantive justice expressed in the substantial issue of the parties' peace agreement in th e form of an acknowledgment of debts and receivables recognized by both parties (debtors and creditors) as stated in the deed of recognition made before the Notary Damar Susilowati in Semarang on August 31, 2007 through an examination at the PKPU stage. This process indicated that it had been accepted (homologous) by the Commercial Court in its decision Number: 77/Pdt.Sus/PKPU/2015/PN. Commerce. Jkt. Pst and has permanent legal force (inkracht van gewijsde).

The Article 281 paragraph (1) of the Bankruptcy Law and PKPU states that reconciliation is accepted based on the approval of the creditors as follows:

a. The approval of more than (a half) of the number of concurrent creditors whose rights are recognized that present at the creditors' meeting as referred in the Article 268 of the UUK including creditors (as referred to the Article 280 of the UUK), represented by at least $2 / 3$ (two thirds) part of all claims.

b. The approval of more than (a half) of the number of creditors whose receivables are guaranteed by that pledge, fiduciary guarantee, mortgage, and other collateral rights in attendance and represent at least 2/3 (two thirds) of all claims.

The peace that has been agreed upon by the creditors must be homologated in the court, while the courts can accept or reject the examination request for homologation. The decision to ratify the peace is binding on parties; both debtors and creditors who agree or disagree with the peace. In the event that the reconciliation plan is rejected at the voting meeting, the supervisory judge must immediately notify the refusal to the Commercial Court by submitting the minutes (note) of the meeting. In that case, the court must declare the debtor bankrupt no later than one day after the court receives notification from the supervisory judge.

After the suspension of debt payment obligations is granted, the PKPU can be terminated. Those who can apply for the termination of PKPU are at the request of the supervisory judge, the management, creditors, and the initiative of the Commercial Court. Meanwhile, several reasons to apply for the termination of PKPU are: ${ }^{19}$

1. The debtor acts in bad faith in managing his assets, during the time of suspension of debt payment obligations.

2. The debtor has harmed or attempted to harm his creditor.

3. The debtor violates the Article 240 paragraph (1) of the UUK which requires the debtor to act regarding his assets based on the authority given by the management.

4. The debtor fails to carry out the actions required by the court at the time or after the suspension of the obligation to pay the debt was given, or fails to carry out the actions required by the management for the benefit of debtor's assets.

5. During the period of postponement of the obligation to pay debts, the condition of the debtor's assets is no longer possible to continue the postponement of the obligation to pay debts.

6. The condition of debtors cannot be expected to fulfill their obligations to creditors on time.

\footnotetext{
${ }^{18}$ Ibid, p. 107.

${ }^{19}$ Ibid, p. 152.
} 
If the postponement of the obligation to pay debts is terminated based on previous reasons, the debtor must be declared bankrupt in the same decision as the decision on the declaration of bankruptcy as a result of the decision to suspend the obligation to pay debts. This has been regulated in in the Article 11, the Article 12, the Article 13 and the Article 14 of the Bankruptcy Law.

The matching of receivables made by the curator was in accordance with the Article 116 of the Bankruptcy Law and PKPU which states: "the curator is obliged to match the calculation of receivables submitted by the Creditor with the records that have been made previously and the statement of the Bankrupt Debtor", and continued with the Article 117 of the Bankruptcy Law and PKPU which state: "the curator is obliged to include the approved receivables into a list of receivables that are temporarily recognized, while the disputed receivables including the reasons are included in a separate list". The curator pursuant to the Article 69 paragraph (1) of the Bankruptcy Law states: "the task of the curator is to administer and settle the bankruptcy estate". The article does not state that the curator in his duties has the authority to cancel the deed of peace that has been agreed upon by the parties during the examination at the PKPU stage, because basically, a peace agreement is a document that contains the conditions agreed upon by the parties to end a dispute as the result of a peace effort through a mediator at the PKPU stage, while a peace deed is a deed that contains the contents of a peace agreement and judge's decision that strengthen the agreement peace (homologation).

It is also in line with the Article 1851 of the Civil Code that:

"Peace is an agreement which contains surrendering, promising or withholding an item, where both parties end a case being examined by the court or prevent a case from arising as long as it is made in writing."

In the Article 1868 of the Civil Code, it is also stated that: "an authentic deed is a deed made in the form determined by law by or before a public official authorized at the place where the deed was made". ${ }^{20}$ However, notary is a public official that is authorized to make an authentic deed and has other authorities as referred to this law and the Article 1 paragraph (1) UUJN. A notarial deed is a perfect written evidence (volledijg bewijs) as described in the Article 1 point 1 and the Article 15 Paragraph (1) UUJN. The previous evidence is made to guarantee and obtain an absolute legal certainty regarding the certainty of the date, month, year, contents of the deed, time, signature and place of making the deed.

It is highly clear that the authority of the curator in the verification stage to match accounts receivable does not state the grant of authority to regulate the event of nullifying a peace deed agreed by the parties that have been examined at the PKPU stage. The deed made before a Notary is formal evidence that is authentic and perfect, and it does not need to be proven by the existence of payable accounts between the debtor and the creditor. Therefore, the PKPU peace deed agreed by the parties and has been homologated by the court has a legal certainty and executive power as a court decision with its permanent legal force (inkracht van gewijsde).

\section{Conclusion}

Based on the analysis, this study could conclude some points.

a. Curator's authority at the verification stage

The curator in bankruptcy law was emerged due to the bankruptcy decision and his duty to manage and settle the bankruptcy estate which is divided into three stages, namely inventory stage, verification stage, and settlement stage. The determination of the curator in the debt matched that has been notarized by the parties at the PKPU reconciliation stage and homologated by the court is not in accordance with the principles of civil procedural law, because the curator is not an organ of the court. There is a necessary to limit the broad interpretation of the curator's authority, so that the PKPU peace deed agreed by the parties and homologated by the court can be carried out with legal certainty.

${ }^{20}$ A. A. Andi Prajitno, Series B, loc.cit. 
The curator's authority is to administer and settle the bankruptcy estate. This does not mean that the curator has the authority to make a determination on bankruptcy assets, because all decisions regarding the management and settlement of bankrupt assets are determined by the court in accordance with the Article 91 of the Bankruptcy Law and PKPU. The curator's obligation to match the calculation of receivables submitted by creditors is essentially only administrative; not to make a determination in the PKPU peace deed agreement, because a peace agreement is a document that contains the conditions agreed upon by the parties to end a dispute as the result of a peace effort through a mediator at the PKPU stage, while a peace deed is a deed that contains the contents of a peace agreement and judge's decision that strengthen the agreement peace (homologation).

b. Legal certainty of the peace deed in the bankruptcy decision

Legal certainty is the ratio of legal norms. It is also the heart of the rule of law, and the broadest basis for the establishment of a legal regulation. In connection with the peace deed made in the bankruptcy proceedings, the point is the legal certainty of the peace deed, where this legal certainty still leads to justice, because legal certainty is also an instrument of justice.

Basically, the PKPU peace deed which has been homologated by the bankruptcy decision has a legal basis, namely the Article $130 \mathrm{HIR} / 154 \mathrm{RBg}$ modified in the form of PERMA Number 01 of 2008 and also heeded in PERMA Number 1 of 2016 which explain that peace agreement/peace deed made by the parties have the same binding force as the judge's decision at the final level. However, factually in bankruptcy procedural law, the curator always re-calculates the notarized payable accounts at the verification stage.

\section{Recommendation}

This study could provide recommendations as an overview for future concepts.

a. The legislators must revise the Article 281 of the PKPU Bankruptcy Law regarding its meaning (understanding), so that the meaning is in accordance with the main legal material, namely:

1) The existence of legal material of "plan".

2) The existence of legal material of "approval".

3) The existence of legal material of "peace".

This is done in the hope of providing definite guidelines to limit the wide interpretation of the curator's authority and to suit legal material.

b. The legislators must revise the Article 281 of the Bankruptcy Law and PKPU related to their institutions regarding the peace agreement to be made in writing before a Notary and submitted back to the court to get a confirmation in the homologation decision. Based on the Article 1851-1864 of the Civil Code, the Article 130 HIR/154 RBg., PERMA No. 01 of 2008 and PERMA No. 1 of 2016 that a peace agreement or peace deed will have legal force when it fulfills several conditions, namely:

1) The peace agreement/deed ends the case

The peace agreement/deed must end the case completely. There is no longer a dispute, because everything has been arranged and the settlement has been formulated in the deed. As long as there are still some cases that have not been resolved in the agreement, the peace deed contains formal defects.

\section{2) The peace agreement/deed is made in written form}

An authentic deed made by a Notary is justified that the peace agreement submitted in writing provides a strong and binding legal certainty in its proof.

3) The party who makes the agreement is the person who has a power 
This is based on the Article 1852 which says: "to be able to make a peace, a person must be authorized to relinquish his rights over the things in the peace". Based on the article, a person who can make a peace agreement is a person who has a position and capacity as persona standi in judicio.

\section{References}

\section{Legal Documents}

Book of the Criminal Law (Burgerlijk Wetboek voor Indonesie)

Herziene Indonesisch Reglement (HIR)

Rechtreglement voor de Buitengewesten (R.Bg)

Law Number 37 of 2004 on Bankruptcy and Postponement of Debt Payment Obligation.

Law Number 2 of 2014 concerning Modifications on Law Number 30 of 2004 on Notary Position.

Regulation of Prime Court Number 01 of 2008 on Procedure of Mediation in the Court.

Regulation of Prime Court Number 1 of 2016 on Procedure of Mediation in the Court.

Indonesian Presidential Decree No. 44 of 1999 on the Formulation of Law and Conceptual Form of Law, Conceptual Regulation of Government and President, dated on 19 May 1999, Legal Paper of the Republic of Indonesia in 1999 Number 70.

\section{Books}

A. A. Andi Prajitno. 2020. Pengetahuan Praktis Tentang Apa dan Siapa Notaris di Indonesia. The Sixth Edition. Surabaya: CV. Perwira Media Nusantara.

Dyah Ochtorina Susanti and A’an Efendi. 2013. Penelitian Hukum. Jakarta: Sinar Grafika.

Tatik Sri Djatmiati and Philipus M. Hadjon, 2005. Argumentasi Hukum. Yogyakarta: Gajah Mada Universitas Press.

Ivida Dewi Amrih Suci. 2020. Hukum Kepailitan: Karakteristik Hukum Acara Renvoi Prosedur Dalam Perkara Kepailitan. The First Edition. Yogyakarta: LaksBang Justitia.

Sudikno Mertokusumo. 2006. Hukum Acara Perdata Indonesia. The Second Edition. Yogyakarta: Liberti.

Sudikno Mertokusumo. 1999. Mengenal Hukum Suatu Pengantar. The Third Edition. Yogyakarta: Liberti.

A. A. Andi Prajitno. 2018. Kewenangan Notaris: Akta Otentik Notaris, Seri B. Surabaya: CV. Putra Media Nusantara.

M. Hadi Shubhan. 2019. Hukum Kepailitan. The Sixth Edition. Jakarta: Kencana, Prenadamedia Group.

Ivida Dewi Amrih Suci dan Herowati Poesoko. 2016. Hukum Kepailitan: Kedudukan dan Hak Kreditor Separatis atas Benda Jaminan Debitor Pailit. The Second Edition. Yogyakarta: LaksBang PRESSindo.

Herowati Poesko. 2013. Dinamika Hukum Parate Executie Obyek Hak Tanggungan. Revised Edition. Yogyakarta: Aswaja Pressindo.

\section{Short Biography}

www.scirj.org

(C) 2021, Scientific Research Journal

http://dx.doi.org/10.31364/SCIRJ/v9.i07.2021.P0721686

This publication is licensed under Creative Commons Attribution CC BY. 
Iqbal Tamrin, S. H. is a student at Master of Notary at the Faculty of Law, Universitas Jember

Dr. Ermanto Fahamsyah, S. H., M. H. is a lecturer at the Faculty of Law, Universitas Jember

Dr. Ivida Dewi Amrih Suci, S. H., M. H., M. Kn. is a lecturer at the Faculty of Law, Universitas Jember 